\title{
Effect of testicular damage induced by cryptorchidism on insulin-like growth factor I receptors in rat Sertoli cells
}

\author{
M. Antich, E. Fabian, J. Sarquella and L. Bassas* \\ Department of Andrology, Instituto de Urología, Nefrologia y Andrología, Fundación Puiguert, Barcelona, \\ Spain
}

\begin{abstract}
The distribution and density of functional insulin-like growth factor I (IGF-I) receptors in cryptorchid and scrotal rat testes and epididymides during gonadal development were studied. Cryptorchidism was induced by unilateral gubernaculectomy in 4-day-old animals, and organs were studied at 15,30,60 and 90 days of age. Tissue membranes were assayed for ${ }^{125}$ I-labelled IGF-I binding. Characterization and specificity of binding sites showed that both normal and contralateral undescended testes and epididymides exhibited typical type 1 IGF receptors. In normal testes, IGF-i receptor density was $20.6 \mathrm{nmol} \mathrm{g}^{-1}$ wet mass at day 15 , and decreased to $12.8 \mathrm{nmol} \mathrm{g}^{-1}$ wet mass at adult age (day 90). Cryptorchid testes showed IGF-I receptor concentrations similar to normal testes at day 15 and day 30, but in postpubertal stages displayed a divergent pattern, with a continuous increase at day 60 and day 90 , reaching a higher density than those found for immature ages $\left(62 \mathrm{nmol} \mathrm{g}^{-1}\right.$ wet mass). Both normal and cryptorchid epididymides had a similar concentration and a comparable decrease in IGF-I receptors throughout development. In studies with immunohistochemical techniques ( $a$ IR-3 antibody), IGF-I receptors were found in primary spermatocytes, Sertoli cells and Leydig cells. Cryptorchid tubules showed a lack of germinal epithelium and a marked increase of immunoreactive IGF-I receptors in Sertoli cells, compared with normal tubules from scrotal testes. Intense immunoreactivity for IGF-I receptors was present in the principal cells of epididymal tubules in both normal and cryptorchid organs. These results suggest that tubular damage induced by cryptorchidism in rats is associated with changes in the local regulation of IGF-I receptors.
\end{abstract}

\section{Introduction}

The complex process of germ cell differentiation in males involves, beyond the action of gonadotrophins and androgens, the concurrence of a number of growth and regulatory substances. These substances establish a network of paracrine interactions within the testis, between the interstitial compartment, the Sertoli cells and the germinal cells, in a unique cytoarchitectural microenvironment (Bardin et al., 1990; Skinner, 1991).

Insulin-like growth factor I (IGF-I) is a firm candidate for participation in the local regulation of spermatogenesis in mammals. A complete intratesticular system of IGFs, composed of peptides, receptors and binding proteins, exists in the testis (Ritzen, 1983; Skinner, 1991). Immunoreactive IGF-I has been identified in testicular extracts of rats (D'Ercole et al., 1984; Handelsman et al., 1985). Sertoli cells and Leydig cells from different species can secrete IGF-I in vitro (Tres et al., 1986; Smith et al., 1987; Vannelli et al., 1988; Forti et al., 1989; Hansson et al., 1989), and this secretion is further stimulated by gonadotrophins (Closset et al., 1989; Cailleau ef al, 1990;

\footnotetext{
*Correspondence.
}

Received 17 November 1994.
Naville et al., 1990; Spiteri-Grech ef al., 1991) and growth hormone (Closset et al., 1989; Spiteri-Grech et al., 1991). Localization of immunoreactive IGF-I indicates that the peptide is present in Sertoli cells, primary pachytene spermatocytes, and some Leydig cells (Tres et al., 1986; Vannelli et al., 1988; Forti $e$ al., 1989), although in situ hybridization experiments in humans suggest that mRNA encoding IGF-I may not be produced in seminiferous tubules (Zhou and Bondy, 1993a). Specific receptors for IGF-I are expressed in Sertoli cells (Borland et al., 1984; Oonk and Grootegoed, 1988), and in Leydig cells from rats (Handelsman et al., 1985; Lin et al., 1986a) and humans (Vannelli et al., 1988; Forti et al., 1989). Germinal cells may also be a source of immunoreactive IGF-I receptor and mRNA encoding the IGF-I receptor (Zhou and Bondy, 1993a).

A number of regulatory mechanisms of IGF-I action in testes have been described. The concentration of IGF-I and its receptor is high in immature rat testes and decreases with gonadal development and sexual maturation (Oonk and Grootegoed, 1988; Hansson et al., 1989). Some IGF-binding proteins (IGFBP), which modulate the transport and bioavailability of IGF-I, are under the inhibitory influence of FSH in Sertoli cells (Cailleau et al., 1990; Smith et al., 1990; Smith et al., 1992), whereas LH stimulates IGFBP secretion in Leydig cells 
in culture (Cailleau et al., 1990). LH and hCG increase the number of IGF-I receptors in Leydig cells (Lin et al., 1987, 1988; Perrard-Sapori et al., 1987; Nagpal et al., 1991). Studies in vivo show an increase in testicular IGF-I in rats with induced tubular damage and spermatogenic arrest (Bartlett ef al, 1990; SpiteriGrech et al., 1991). It is thus possible that the IGF-I system could participate in local adaptive responses to certain pathophysiological conditions of the testis; however, there are no available studies on IGF-I receptor expression in such circumstances.

Cryptorchidism is a well identified clinical condition which causes male infertility. It constitutes a model of primary testicular damage that can be experimentally reproduced in vivo without altering the hormonal milieu (Rajalakshmi and Prasad, 1974; Bergh, 1983; Bergh et al., 1987). In this study, the changes in density and the histological distribution of IGF-I receptors throughout development in testis and epididymis from rats with induced unilateral cryptorchidism were investigated.

\section{Materials and Methods}

\section{Experimental cryptorchidism}

Cryptorchidism was unilaterally induced in male Wistar rats by microsurgical distal gubernaculectomy at day 4 after birth under anaesthesia with hypothermia plus ethyl ether. Spermatogenesis is initiated in Wistar rats soon after day 15 of age, when testes are still abdominal. Puberty and testicular descent is completed at about day 35, and after 3 months of age animals are fully developed (Bergh and Helander, 1978; Bergh et al., 1978). Gubernaculectomy prevents testicular descent and scrotal development (Bergh et al., 1978). Animals were killed by decapitation at 15, 30, 60 and 90 days of age. Testes were removed, measured and weighed, and then frozen in isopentyl alcohol and kept at $-70^{\circ} \mathrm{C}$ until processing.

\section{Tissue preparation}

Testes and epididymides ( 30 abdominal and 42 contralateral scrotal) were minced with a glass homogenizer in $1 \mathrm{mmol}$ $\mathrm{Na} \mathrm{HCO}_{3} \mathrm{I}^{-1}$ with protease inhibitors $(0.5 \mathrm{mg}$ Bacitracin $\mathrm{ml}^{-1}, 1 \mu \mathrm{g}$ phenylmethyl sulfonyl fluoride (PMSF) $\mathrm{ml}^{-1}, 1 \mu \mathrm{g}$ Aprotinin $\mathrm{ml}^{-1}$ ). A first centrifugation was performed at $600 \mathrm{~g}$ for $10 \mathrm{~min}$ to eliminate gross tissue remnants and nuclei. The supernatant was centrifuged again at $12000 \mathrm{~g}$ for $30 \mathrm{~min}$ and washed. The pellet was resuspended in Hepes buffer $(100 \mathrm{mmol}$ Hepes $]^{-1}, 120 \mathrm{mmol} \mathrm{NaCl}^{-1}, 1.2 \mathrm{mmol} \mathrm{MgSO}_{4} \cdot 7 \mathrm{H}_{2} \mathrm{Ol}^{-1}$, $2.5 \mathrm{mmol} \mathrm{KCl} \mathrm{l}^{-1}, 15 \mathrm{mmol}^{-1}$ sodium acetate $\mathrm{l}^{-1}, 10 \mathrm{mmol}$ glucose $\mathrm{l}^{-1}, 1 \mathrm{mmol}^{\mathrm{E} D T A \mathrm{I}^{-1}}{ }^{-1} \mathrm{pH}$ 7.6. Protein concentration was determined by the Bradford method (Bio-Rad Laboratories, Madrid) and adjusted between 0.5 and $1.5 \mathrm{mg} \mathrm{ml}^{-1}$. The average yield of membrane protein was $8 \mathrm{mg} \mathrm{g}^{-1}$ wet mass of tissue (range 6.2-9.6), and was similar for control and cryptorchid organs throughout development. Membranes were stored at $-70^{\circ} \mathrm{C}$ until binding experiments were performed.

\section{Binding studies}

Membrane suspensions (25-75 $\mu \mathrm{g}$ protein per tube) were incubated with constant amounts of ${ }^{125}$ I-labelled human recom- binant IGF-I (10 000 c.p.m. per tube, $170 \mathrm{pg} \mathrm{ml}^{-1}$, Amersham, Madrid), for $16 \mathrm{~h}$ at $4^{\circ} \mathrm{C}$ in a total volume of $150 \mu \mathrm{l}$ in Hepes buffer plus $1 \%(\mathrm{w} / \mathrm{v}) \mathrm{BSA}$, and $0.5 \mathrm{mg}$ Bacitracin, $\mathrm{pH} 7.8$. Nonspecific binding was determined by coincubation with $250 \mathrm{ng}$ unlabelled IGF-I ml ${ }^{-1}$ (Bachem, H-5555, Bubendorf). The percentage of specific binding was corrected according to the protein concentration of each sample. The relationship between ${ }^{125}$ I-labelled IGF-I specific binding and membrane protein concentration within the range $0.25-2 \mathrm{mg} \mathrm{ml}^{-1}$ was linear $(r=0.998)$. This allowed normalization of specific binding to $1 \mathrm{mg} \mathrm{ml}^{-1}$ (50 $\mu \mathrm{g}$ per tube) membrane protein in each case. After incubation, membranes were centrifuged at $12000 \mathrm{~g}$ for $10 \mathrm{~min}$ at $4^{\circ} \mathrm{C}$. The pellet was washed with $250 \mu \mathrm{l}$ cold PBS and centrifuged again at $12000 \mathrm{~g}$ for $3 \mathrm{~min}$. After a final aspiration of the supernatant and drying, the tips of the tubes were cut and placed in counting vials, and the radioactivity associated with membranes was determined. The initial characterization showed maximum binding at $\mathrm{pH}$ 7.8-8.0, which decreased at lower $\mathrm{pH}$ (data not shown). Degradation was determined using trichloroacetic acid (final concentration, $5 \% \mathrm{w} / \mathrm{v}$ ) to precipitate intact peptide. Total degradation of ${ }^{125} \mathrm{I}$-labelled IGF-I during incubation conditions ( $16 \mathrm{~h}$ at $4^{\circ} \mathrm{C}$ ) was $12 \%$. Specific degradation induced by membranes in the binding assay averaged $3.5 \%$, and was not influenced by the protein concentration of tissue preparations. Control binding studies were carried out using membranes previously incubated and washed $\left(24 \mathrm{~h}\right.$ at $\left.4^{\circ} \mathrm{C}\right)$ with Hepes assay buffer. This method eliminates most endogenous IGF-I and binding proteins present in the membrane preparation (Grizzard et al., 1984). Aliquots of the same batch in the same experiment were used to compare the percentage of labelled IGF-I as well as the displacement of saturating concentrations of IGF-I and insulin. No differences were observed between washed and unwashed membrane preparations (data not shown). This finding suggests that IGF-I was mainly bound to a true type 1 specific receptor, and that endogenous contaminants were unlikely to be present in the preparations used for analysis.

Experimental variation was minimized by measuring IGF-I binding to scrotal and cryptorchid testes throughout development in a single assay using the same batch of ${ }^{125}$ I-labelled IGF-I. Simultaneous study of membranes from scrotal and cryptorchid organs in the same assay allowed appropriate comparison of the binding characteristics of different tissues. Specificity studies and subsequent Scatchard analyses were performed by coincubating labelled IGF-I with different concentrations of unlabelled IGF-I, insulin or a monoclonal antiIGF-I receptor antibody ( $\alpha$ IR-3 clone, Oncogene Science Inc., Uniondale, NY). This antibody specifically inhibits IGF-I binding to its own receptor, and does not compete for insulin binding (Jacobs et al., 1986).

\section{Immunohistochemistry}

Testes and epididymides from normal $(n=4)$ and cryptorchid $(n=5)$ animals were used for immunohistochemical localization of IGF-I receptors. Frozen testicular and epididymal tissue fragments were fixed in Bouin's solution and embedded in paraffin wax. Sections, $5 \mu \mathrm{m}$ thick, were stained using the immunoperoxidase technique. Paraffin wax was removed from 
Table 1. Testicular mass of control $(n=42)$ and cryptorchid $(n=30)$ rat testes during development

\begin{tabular}{lccccc}
\hline & & \multicolumn{3}{c}{ Age (days) } \\
Treatment & & 15 & 30 & 60 & 90 \\
\hline Control & $n$ & 8 & 14 & 9 & 11 \\
Cryptorchid & Mass (g) & $0.19 \pm 0.03$ & $1.09 \pm 0.18$ & $2.47 \pm 0.31$ & $3.16 \pm 0.55$ \\
& $n$ & 9 & 9 & 6 & 6 \\
& Mass (g) & $0.11 \pm 0.06$ & $0.70 \pm 0.22$ & $1.06 \pm 0.34$ & $1.29 \pm 0.55$ \\
\hline
\end{tabular}

Values are means $\pm \mathrm{SEM} ; n=$ number of testes.

the sections and they were preincubated with normal horse serum and incubated with anti-human IGF-I receptor monoclonal antibody $\alpha \operatorname{IR}-3\left(5 \mu \mathrm{g} \mathrm{ml}^{-1}\right)$, in PBS, $2 \% \mathrm{BSA}(\mathrm{w} / \mathrm{v})$ for $18 \mathrm{~h}$ at room temperature as described by Vanelli et al. (1988) and Forti et al. (1989). Thereafter, the sections were incubated with biotinylated horse antimouse IgG $(\mathrm{H}+\mathrm{L})(<1 \%$ crossreactivity with rat $\mathrm{IgG}$ ), produced in horse (Vector, Burlingame, CA), at 1:100 titre for $45 \mathrm{~min}$. Antigen-antibody complexes were identified using the avidin-biotin-peroxidase complex, with a Vectastatin $A B C$ kit (Vector). Peroxidase activity was demonstrated with a solution of $0.07 \%(\mathrm{w} / \mathrm{v}) 3,3^{\prime}$ diaminobencidine tetrahydrochloride (DAB, Sigma Chemical Co., St Louis, MO) in PBS containing $0.08 \%(\mathrm{v} / \mathrm{v})$ hydrogen peroxide. Sections were counterstained with haematoxylin. The specificity of immunohistochemical reactions was verified by using the following procedures: (i) incubation of sections with non-immune mouse serum instead of primary antibody; (ii) omission of primary or secondary antibodies; and (iii) incubation with different dilutions of monoclonal antibody (5, 3 and $0.5 \mu \mathrm{g} \mathrm{ml}^{-1}$ ). Sections from control and treated organs were always processed in the same experiment.

\section{Statistical analyses}

Analysis of differences between control and treated organs used the Kruskal Wallis test. Comparisons within age-matched groups were performed with the Mann-Whitney U test.

\section{Results}

\section{Effects of cryptorchidism on testis and epididymis}

Cryptorchid testes showed a progressive delay in testicular growth compared with control organs (Table 1). The reduction in mass was $42 \%$ at day 15 , and reached $59 \%$ at day 90 . Undescended epididymides had only slight, nonsignificant changes in mass.

Examination of adult cryptorchid testes under the microscope showed a marked impairment of spermatogenesis. Virtually all the tubules showed a decrease in diameter, and an absence of germinal epithelium. Interstitial spaces remained unchanged under examination by light microscopy examination. Epididymides showed histological changes consisting of a decrease in tubular diameter, an increase in the height of principal cells and vacuolation. (a)

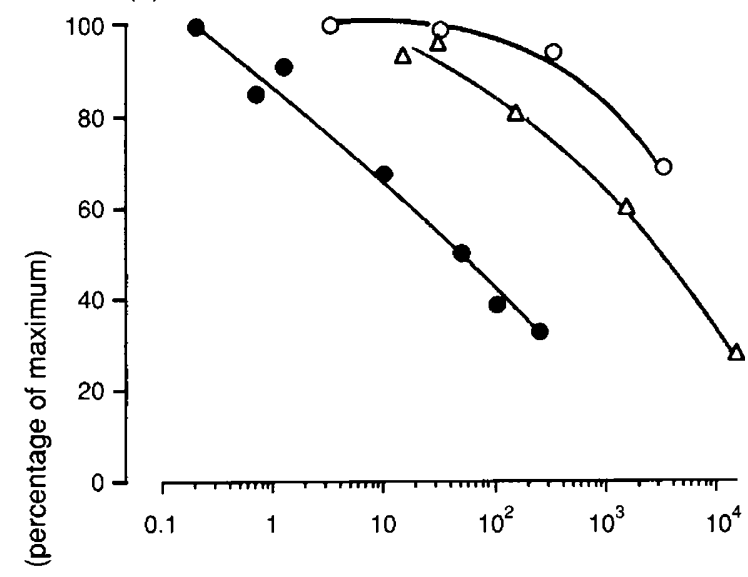

(b)

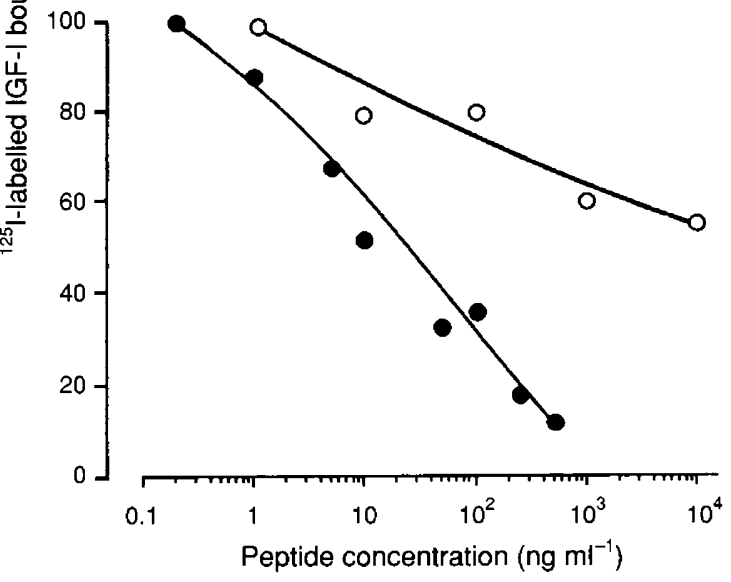

Fig. 1. Specificity of binding of insulin-like growth factor I (IGF-I) to membrane receptors in (a) scrotal testis and (b) epididymis from 30and 90-day-old rats. Triplicate samples of membranes were incubated with ${ }^{125}$ I-labelled IGF-I, in the presence or absence of indicated amounts of unlabelled IGF-I (-), insulin $(O)$ or anti-IGF-I receptor antibody (aIR-3) ( $\triangle)$. Each point represents the mean of two experiments.

\section{Binding studies in membrane suspensions}

Binding studies of IGF-I were performed in membranes prepared from control and cryptorchid rat testes and epididymides at 15, 30, 60 and 90 days of age. Labelled IGF-I appeared to bind to a type 1 IGF receptor in testes and epididymides of rats. Traditional competition studies, using 
Table 2. Analysis of developmental changes in insulin-like growth factor I (IGF-I) receptors in scrotal or cryptorchid rat testes

\begin{tabular}{|c|c|c|c|c|c|}
\hline \multirow[b]{2}{*}{ Treatment } & \multirow[b]{2}{*}{ IGF-I receptor } & \multicolumn{4}{|c|}{ Age (days) } \\
\hline & & 15 & 30 & 60 & 90 \\
\hline \multirow[t]{2}{*}{ Scrotal } & $R_{\mathrm{o}}$ (pmol $\mathrm{mg}^{-1}$ protein) & 2385 & 1819 & 939 & 1606 \\
\hline & $R_{\mathrm{o}}\left(\mathrm{nmol} \mathrm{g} \mathrm{g}^{-1}\right.$ mass $)$ & 20.63 & 16.8 & 7.48 & 12.79 \\
\hline \multirow[t]{2}{*}{ Cryptorchid } & $R_{0}\left(\right.$ pmol $\mathrm{mg}^{-1}$ protein $)$ & 2506 & 1934 & 1488 & 9354 \\
\hline & $R_{o}\left(\right.$ nmol g ${ }^{-1}$ mass $)$ & 24.13 & 14.4 & 9.28 & 61.97 \\
\hline
\end{tabular}

Data correspond to an experiment using membranes from two to five organs. Linear correlation of Scatchard plots was always higher than 0.93 . $R_{t}$ : total binding capacity.

membranes from adult animals (90 days), showed that the concentration of unlabelled IGF-I competing for $50 \%$ of the specific binding $\left(\mathrm{IC}_{50}\right)$ was $10 \mathrm{ng} \mathrm{ml}^{-1}$ in both tissues. Insulin was 1000 times less potent in competition for labelled IGF-I (Fig. 1). Scatchard analysis was applied to calculate the dissociation constant $\left(K_{d}\right)$ and the total binding capacity $\left(R_{0}\right)$ in different tissues and ages (Table 2). The effect of coincubating labelled IGF-I and increasing concentrations of the monoclonal antibody, aIR-3, which specifically binds to the IGF-I receptor (Kull et al, 1983) is shown (Fig. Ia). At high concentrations (I5 $\mu \mathrm{g} \mathrm{ml}^{-\mathrm{I}}$ ), $\alpha$ IR-3 could completely abolish specific binding of IGF-I to testicular membranes. These data indirectly confirm that in normal testis, IGF-I was mainly bound to specific IGF-I receptors and not to IGF-binding proteins or to other structurally related receptors (for example insulin and IGF-II).

The specific binding was studied in membranes from 72 testes ( 42 normal and 30 cryptorchid). There was a decrease in IGF-I specific binding in normal testes throughout postnatal development $(P<0.001$, Fig. 2a). Scatchard analysis (Table 2) confirmed that the decrease in binding corresponded to a reduction in receptor binding capacity from $20.6 \mathrm{nmol}$ (day 15) to $12.8 \mathrm{nmol}$ (day 90) $\mathrm{g}^{-1}$ wet mass tissue, while the $K_{\mathrm{d}}$ value remained relatively constant $\left(1.0-1.7 \mathrm{nmol} \mathrm{l}^{-1}\right)$.

Cryptorchid testes showed an initial decrease in specific binding, similar to that observed in normal testes during pubertal development (day 15 and day 30). However, at day 60 and day 90, the specific binding of cryptorchid testes increased and was significantly higher than that of normal testes (Fig. 2a) owing to a rise in the number of receptors of IGF-I (Table 2). Cryptorchid testes at 90 days had 62 nmol receptor $\mathrm{g}^{-1}$ wet mass, which is five times higher than the density of scrotal receptors. Total IGF-I receptor capacity per testis (90 days) was $34.5 \mathrm{nmol}$ in normal organs versus $74.4 \mathrm{nmol}$ in undescended testes. The slopes of the Scatchard plots obtained from scrotal and cryptorchid testes at day 90 were similar (1.5 and $1.6 \mathrm{nmol}$ $1^{-1}$, respectively) (Fig. 3). This finding confirmed that the rise in specific binding was produced by an increase in the number of receptors and not by a change in their affinity.

Binding studies were performed using membrane suspensions from the epididymis. Control epididymides showed a decrease in IGF-I-specific binding during growth (Fig. 2b) from $2130 \mathrm{pmol} \mathrm{mg}^{-1}$ membrane protein at day 15 to $1264 \mathrm{pmol}$ $\mathrm{mg}^{-1}$ protein at day 90 . In general, specific binding and receptor content were similar in both normal and cryptorchid epididymides throughout development. The affinity of the binding sites was $1.2 \mathrm{nmol} \mathrm{I}^{-1}$, and showed no changes between control and undescended epididymides.

\section{Immunohistochemical localization of IGF-I receptors in adult (day 90) testis and epididymis}

High levels of immunoreactivity for IGF-I receptors were detected in the seminiferous tubule. Within the tubules, the strongest signal was found in the cytoplasm of large round cells, which were interpreted as being primary spermatocytes, whereas lower positivity was detected in spermatogonia, early spermatids and in the cytoplasm of Sertoli cells (Fig. 4e). Late spermatids and mature spermatozoa were clearly negative for immunoreactive IGF-I receptor. In the interstitium, most of the Leydig cells showed strong positivity in their cytoplasm (Fig. 4g). Peritubular cells, as well as endothelial cells of interstitial vessels, were negative.

In cryptorchid testes, a clear increase in immunoreactive IGF-I receptors was evident in Sertoli cells compared with contralateral scrotal testes with normal spermatogenesis (Fig. 4a, c). No changes were seen in the interstitial space, either in the distribution or intensity of immunoreactive IGF-I receptors between control and cryptorchid testes.

In epididymides, immunoreactive IGF-I receptors were identified in the membranes and in the cytoplasm of principal cells of the epididymal tubules (Fig. 5). The apical brush border, which contains tall microvilli, also showed IGF-I receptors. Other cell types, such as basal and clear cells, did not express IGF-I receptors. The pattern of IGF-I receptor distribution and the intensity of immunostaining were similar in cryptorchid and scrotal epididymides.

\section{Discussion}

Developmental regulation of IGF-I receptor expression has been described in different tissues and species (Bassas et al., 1988; Zhou and Bondy, 1993b). The results of the study reported here confirm and extend those of Oonk and Grootegoed (1988), which showed that IGF-I receptors are abundant both in the testes and epididymides of rats, and that the density of IGF-I receptors decreases significantly throughout normal postnatal development of those organs. Characterization of IGF-I binding, by competition with insulin or with a monoclonal anti-IGF-I receptor antibody, indicates that the 
(a)

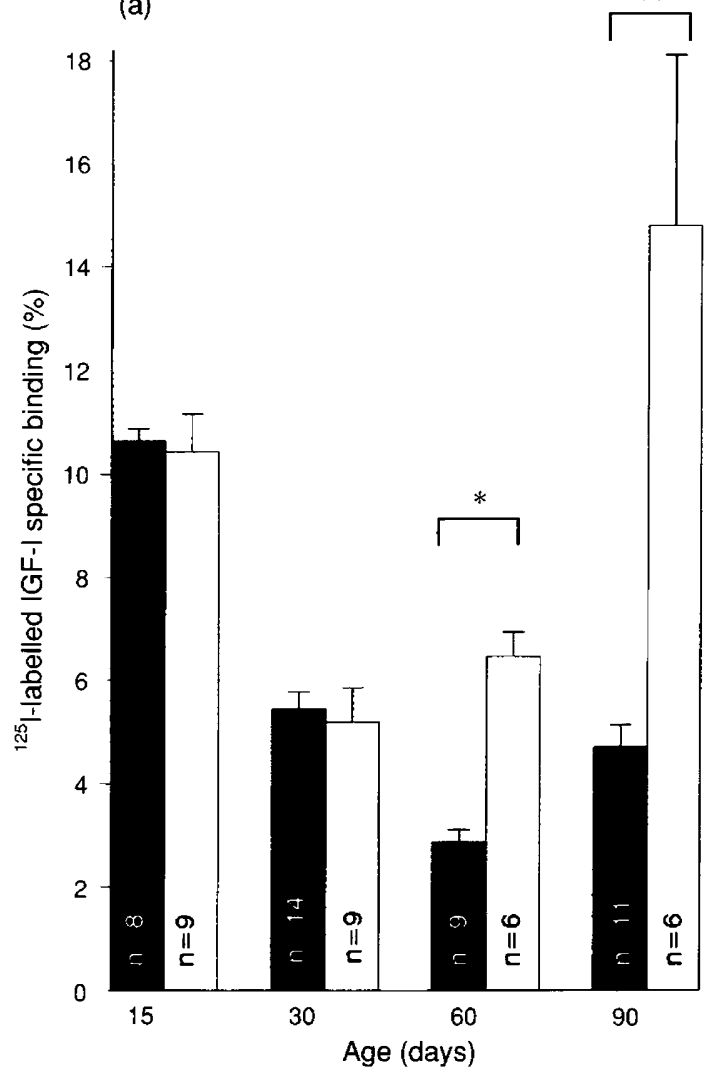

(b)

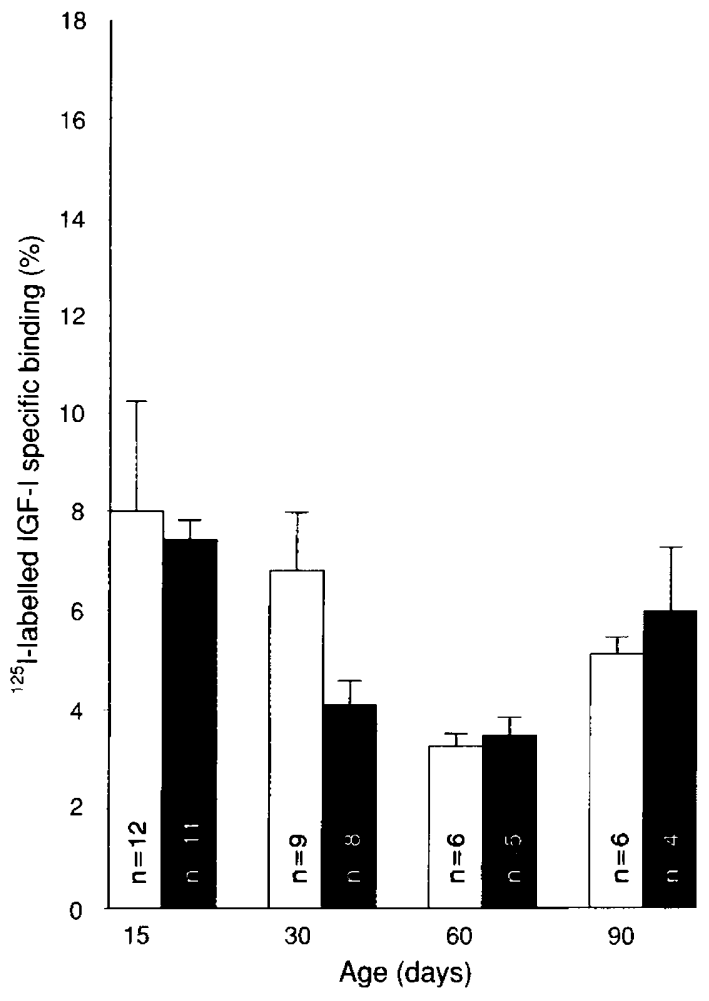

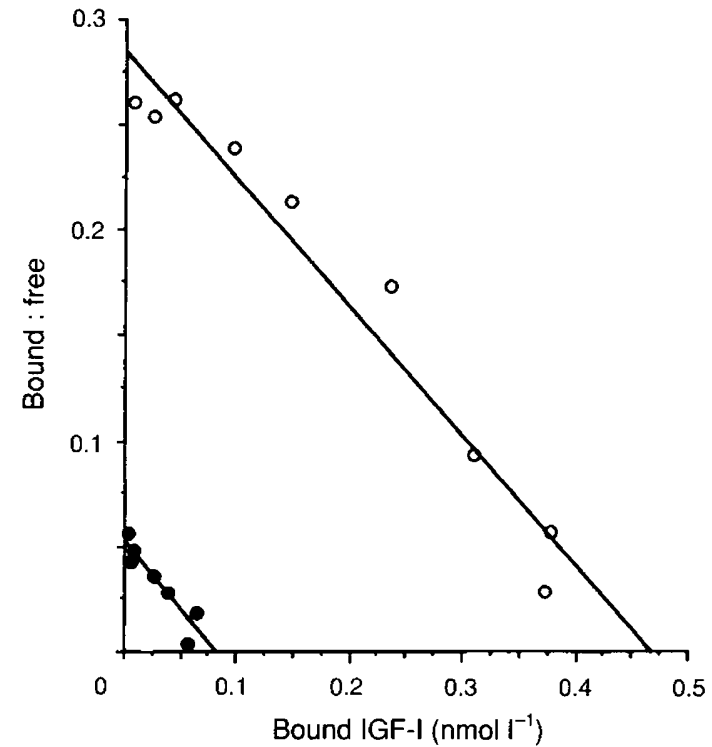

Fig. 3. Scatchard plot of ${ }^{125}$ I-labelled insulin-like growth factor I (IGF-I) binding to testicular membranes from $(\bullet)$ normal and $(c)$ cryptorchid adult rat testes. Specific binding was expressed as the ratio bound:free hormone (B:F) and plotted as function of bound hormone. The means of two separate determinations with triplicate incubations are shown. The slope $\left(k_{a}\right)$ was similar in scrotal and undescended testes. The correlation coefficients of the linear plot were 0.93 and 0.98 for normal and cryptorchid testes, respectively.

binding sites correspond to typical IGF-I receptors, displaying features similar to those reported by Handelsman ef al. (1985) and Oonk and Grootegoed (1988). The changes in IGF-I binding are due to changes in receptor concentration rather than to modifications of receptor affinity. Immunoreactive IGF-I receptors are distributed in the Leydig cells and in the tubular compartment of the testes. Sertoli cells, as well as primary spermatocytes, contain IGF-I receptors.

Cryptorchidism produces a marked and distinct effect on the developmental pattern of testicular IGF-I receptor density. Before sexual maturation is completed (day 15 and day 30 of age) there are no differences in the number of IGF-I receptors between cryptorchid and control organs. However, in the postpubertal period, the IGF-1 receptor concentration in undescended testes is five times higher than normal. The almost complete loss of germ cells seen in cryptorchid testes could theoretically account for an apparent increase in IGF-I receptor density, as mature germ cells express few receptors while contributing significantly to the membrane contents of the preparations tested. Nevertheless, this methodological objection does not invalidate the conclusion because: (1) the total IGF-I receptor capacity per testis showed a two-fold increase in cryptorchid

Fig. 2. Changes in binding of insulin-like growth factor I (IGF-I) to (a) control ( $\square$ ) and cryptorchid ( $\square$ ) testes and (b) control ( $\square$ ) and cryptorchid ( $\boldsymbol{\square}$ ) epididymides during development of rats. Values represent means \pm SEM of ${ }^{125}$ I-labelled IGF-I specific binding of membranes ( $1 \mathrm{mg} \mathrm{ml}{ }^{-1}$ protein) from organs $(n)$ tested in triplicate in the same experiment. Differences between cryptorchid and control testes were significant at 60 days $\left({ }^{*} P<0.01\right)$ and 90 days $(* * P<0.05)$. 

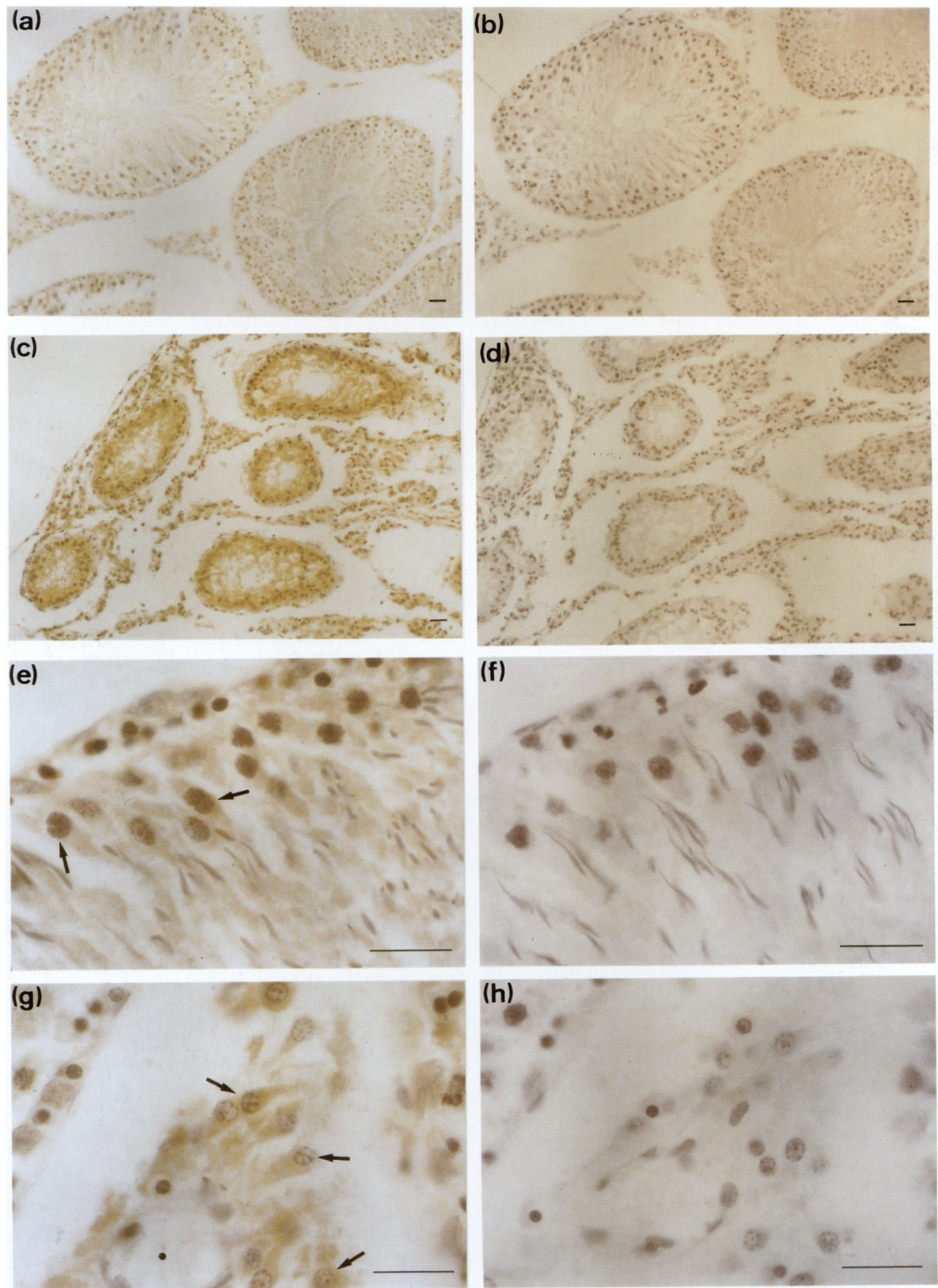

Fig. 4. Immunohistochemistry of insulin-like growth factor I (IGF-I) receptors in normal and cryptorchid adult (day 90) rat testes. Sections from (a) scrotal and (c) cryptorchid testes were incubated with anti-IGF-I receptor antibody aIR-3 $\left(5 \mu \mathrm{g} \mathrm{ml}^{-1}\right)$. Tubules from cryptorchid testes (c) show smaller diameter and absence of germ cells, and intense immunoreactivity for IGF-I receptors in the cytoplasm of Sertoli cells. A more detailed view of normal seminiferous tubule (e) shows positive staining in Sertoli cells and in primary spermatocytes (arrows). The interstitial space (g) shows Leydig cells with clear positivity for IGF-I receptor (arrows) and negative capillary cells $\left({ }^{*}\right)$. Negative controls ( $b, d, f$ and h) were adjacent sections processed in the same way, but primary antibody was substituted by a similar concentration of non-immune mouse serum. All sections were counterstained with haematoxylin. Scale bars represent $25 \mu \mathrm{m}$. 

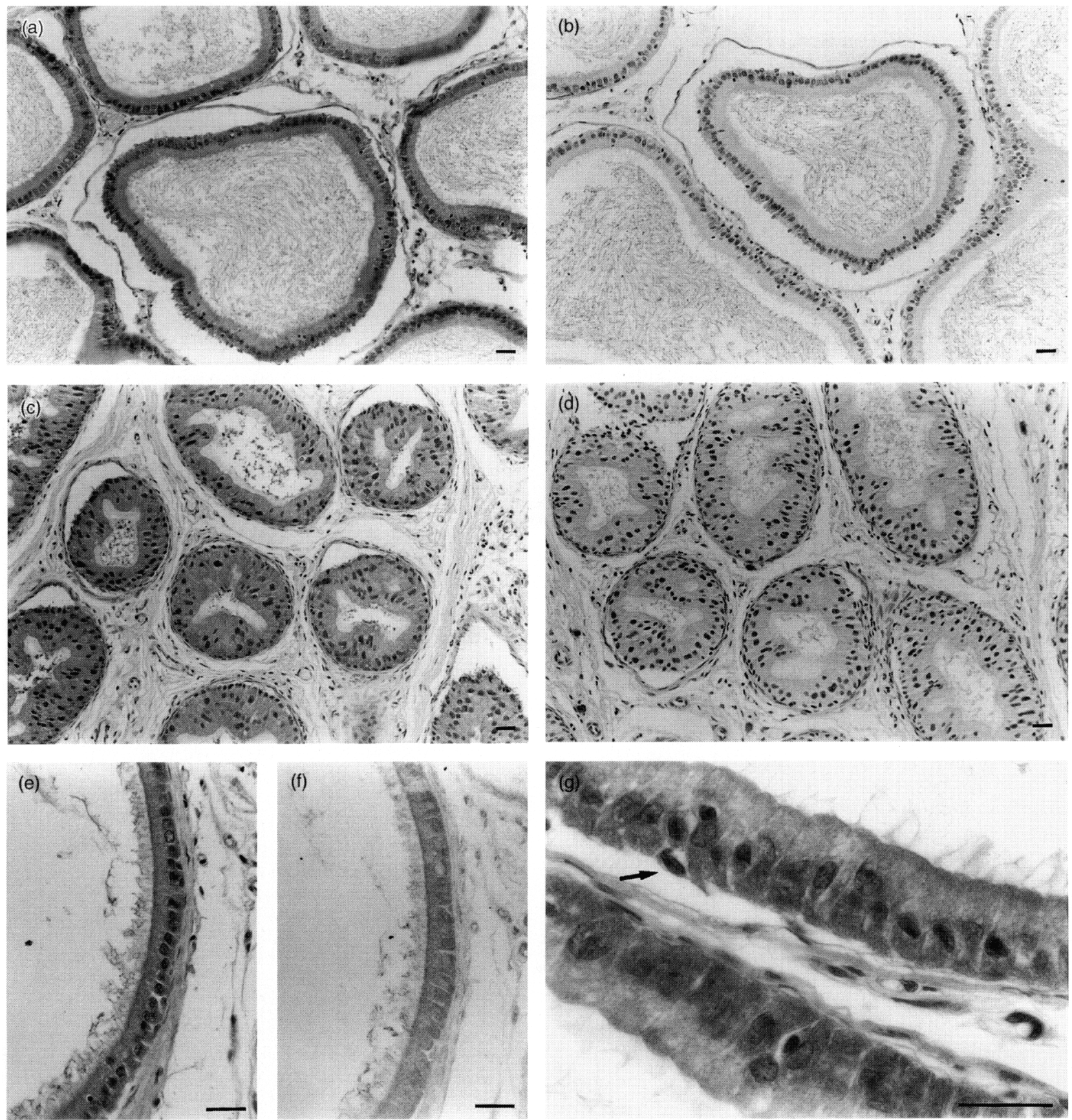

Fig. 5. Localization of insulin-like growth factor I (IGF-I) receptor in normal and cryptorchid epididymal tubules. Sections from (a) scrotal caput epididymis and (c) cryptorchid corpus epididymis show strong immunoreactivity in the membranes and the cytoplasm of principal cells of epididymal tubules. The apical brush border showed intense IGF-I receptor expression (e, $f$ and $g$ ). Other cell types showed no IGF-I receptors (arrow, g). IGF-I receptor intensity was unchanged between epididymides corresponding to scrotal and cryptorchid rats. Adjacent control sections $(b$ and $d$ ) were incubated with non-immune mouse serum instead of primary antibody. All sections were counterstained with haematoxylin, except for (f) in which only 3,3'-diaminobencidine tetrahydrochloride was used. Scale bars represents $25 \mu \mathrm{m}$.

versus scrotal testes at adult age; (2) IGF-I receptor concentration in cryptorchid adult testes ( 90 days) was three times higher than in prepubertal organs ( 15 days), even though differentiated germ cells were absent in both cases; and (3) immunolocalization of IGF-I receptors, using sections of similar thickness, stained in the same experiment, showed an increased expression of the receptor in Sertoli cells but not in other cell types of cryptorchid testis.
Some additional caveats can challenge this simple interpretation. For this reason, significant contamination of tissue preparations by IGFBP was excluded. Moreover, the relative yield in the preparation of membranes was similar both in normal and cryptorchid organs throughout development.

Undescended testes suffer a progressive impairment of spermatogenesis during gonadal development. The first 
morphological changes appear in immature Sertoli cells, and are soon followed by degeneration of spermatocytes (Bergh, 1983). Leydig cells are unaffected initially but will eventually decrease in size, and show impairment of steroidogenic efficiency in adult life (Bergh and Damber, 1978; Bergh et al., 1985; Kerr et al., 1988). The higher temperature present in abdominal testes triggers a sequence of functional and structural events leading to irreversible tubular damage and a rise in gonadotrophin concentrations (Kormano, 1967; Bergh, 1983; Kerr et al., 1988). Altered Sertoli cell function produces a marked decrease in FSH receptors in abdominal testes at 30 days of age (Bergh et al., 1985, 1987). LH receptors are also reduced at this age. Leydig cells are not sensitive to the abdominal temperature, but abnormal paracrine influences from the altered seminiferous tubules could reduce $\mathrm{LH}$ receptors and steroidogenesis (Risbridger ef al., 1981; Bergh et al., 1987). The data shown here provide the first evidence that primary testicular damage in vivo, in the absence of other endocrine alterations, is associated with an increase in the local expression of IGF-I receptors. It is possible that cell-to-cell contacts between Sertoli cells and stage-specific differentiating germ cells could modulate the expression of IGF-I receptors in Sertoli cells (Galdieri et al., 1984). Alternatively, an increase in gonadotrophin concentration could stimulate the synthesis of IGF-I receptors. However, two considerations militate against this hypothesis: (1) the changes in IGF-I receptors affect only undescended testes, whereas scrotal testes from the same animals are unaffected; and (2) high LH and FSH concentrations (Kerr et al., 1988) may have little effect on Sertoli cells when the rise in IGF-I receptors is detected, since LH and FSH receptors are markedly reduced at that time (Bergh et al., 1987).

Specific IGF-I receptors are present in the membranes of rat epididymides throughout development. As for testes, specific binding is higher in immature animals and declines progressively until adulthood. Immunohistochemical localization of IGF-I receptors shows that they are limited to the principal cells of the epididymal epithelium. Typical histological changes were found at 90 days of age in cryptorchid epididymides, in agreement with the study of Rajalakshmi and Prasad (1974). Nevertheless (in contrast to testes), epididymides from cryptorchid rats did not show changes in the number or in the distribution of IGF-I receptors, compared with scrotal organs. IGF-I receptors have not been described previously in the epididymis, although IGF-I is present in rat epididymides (Hansson et al., 1988; Leheup and Grignon, 1993). The peptide is located in the apical cytoplasmic border of the epithelial cells from the epididymis in immature rats. These findings suggest that IGF-I produced in the epididymis or present in the epididymal fluid binds to specific cellular receptors of the epididymal epithelium. The physiological function of IGF-I in the epididymis is unknown, but it may have a role in supporting division and differentiation (Leheup et al., 1989).

IGF-I has been found in peritubular cells, pachytene spermatocytes and Sertoli cells in rats (Tres et al., 1986). A possible physiological role of the IGF-I system in the testis in vivo is suggested, based on many biological effects studied in experiments in vitro. IGF-I potentiates the actions of gonadotrophins on Leydig cells by increasing its sensitivity to LH (Bernier et al., 1986; Perrard-Sapori et al., 1987; Chatelain et al., 1991) and the production of testosterone (Bernier et al., 1986; Lin et al., 1986a, b; Kasson and Hsueh, 1987; Perrard-Sapori et al., 1987; Chatelain et al., 1991; Gelber et al, 1992). IGF-I increases the transport of glucose (Mita et al., 1985; Oonk et al., 1989) and the production of lactate (Oonk et al., 1989) in cultured rat Sertoli cells. Moreover, IGF-I stimulates the synthesis of DNA and the proliferation of pig Sertoli cells in vitro (Jaillard et al., 1987). IGF-I increases the production of premitotic DNA in spermatogonia, and maintains the synthesis of premeiotic DNA in germ cells from rats (Söder et al., 1992). The presence of IGF-I receptors in primary spermatocytes suggests that IGF-I could act through autocrine and paracrine mechanisms as a regulator of spermatogenesis under normal physiological conditions (Spiteri-Grech et al., 1993).

One of the possible mechanisms by which testicular effects of IGF-I can be regulated is the modification of the density of its receptors. This may result in amplification of the biological responses to local concentrations of IGF-I. The results of this study show that damage to seminiferous tubules induced by cryptorchidism is followed by a specific increase in IGF-I receptors in Sertoli cells in vivo. Other clinical conditions producing testicular injury and germ cell loss could share a similar compensatory response (Antich et al., 1993). Further studies will be necessary to elucidate whether this upregulatory mechanism also includes changes in the testicular production of IGF-I, or in the synthesis of some of its binding proteins.

This work was supported by the Spanish Fondo de Investigación Sanitaria (Grant 91/0233). The authors thank F. Algaba (Pathology Laboratory) and R. Castellet (Hormonal Laboratory) for their thoughtful comments. They are grateful to E. Mato, R. M" Farre, M. Vilaseca, M. Mas and I. Moncunill for technical assistance.

\section{References}

Antich M, Fabian E, Castellet R and Bassas L (1993) Changes in receptors for IGF-1 in impaired spermatogenesis Scientific Program of the 5 th International Congress of Andrology pp $21 \mathrm{I} \mathrm{Ed}$. Tokohsha Co. Ltd, Tokyo

Bardin CW, Morris PL and Chen CLH (1990) Autocrine and paracrine gonadal peptides. In Recent Progress in GnRH and gonadal peptides pp 367-382 Eds P Bouchard, F Haour, P Franchimont and B Schatz. Elsevier, Paris

Bartlett JMS, Spiteri-Grech J and Nieschlag E (1990) Regulation of insulin-like growth factor I and stage-specific levels of epidermal growth factor in stage synchronized rat testes Endocrinology 127 747-758

Bassas L, Lesniak MA, Serrano J, Roth J and De Pablo F (1988) Developmental regulation of insulin and type I insulin-like growth factor receptors and absence of type 11 receptor in chicken embryo tissues Diabetes 37 637-644

Bergh A (1983) Early morphological changes in the abdominal testes in immature unilaterally cryptorchid rats Internutional joumal of Androlowy 6 $73-90$

Bergh A and Damber JE (1978) Morphometric and functional investigation on the Leydig cells in experimental unilateral cryptorchism in the rat International journal of Andrology 1 549-562

Bergh A and Helander HF (1978) Testicular development in the unilaterally cryptorchid rat Intemational Journal of Andrology 1 440-458

Bergh A, Helander HF and Wahlqvist L (1978) Studies on factors governing testicular descent in the rat, particularly the role of gubernaculum testis Internutional journal of Andrology $1342-356$

Bergh A, Nikula H, Damber JE, Clayton R and Huhtaniemi I (1985) Altered concentrations of gonadotrophin, prolactin and $\mathrm{GnRH}$ receptor and endogenous steroids in the abdominal testes of adult unilaterally cryptorchid rats journal of Reproduction and Fertility 74 279-286

Bergh A. Damber JE and Huhtaniemi I (1987) Intratesticular steroids and gonadotrophin receptor concentrations in the testes of immature unilaterally cryptorchid rats Intemational Journal of Andrology 10 803-808 
Bernier M, Chatelain P, Mather JP and Saez JM (1986) Regulation of gonadotropin receptor, gonadotropin responsiveness, and cell multiplication by somatomedin-C and insulin in cultured pig Leydig cells Journal of Cellular Physiology 129 257-263

Borland K, Mita M, Oppenheimer CL, Blinderman A, Massague J, Hall PF and Czech MP (1984) The actions of insulin-like growth factor I and II on cultured Sertoli cells Endocrinology 114 240-246

Cailleau J, Vermeire S and Verhoeven G (1990) Independent control of the production of insulin-like growth factor I and its binding protein by cultured testicular cells Molecular Cell Endocrinology 69 79-89

Chatelain PG, Sanchez P and Saez JM (1991) Growth hormone and insulin-like growth factor I treatment increase testicular luteinizing hormone receptors and steroidogenic responsiveness of growth hormone-deficient dwarf mice Endocrinology 128 1857-1862

Closset J, Gothot A, Sente B, Scippo ML, Lgout A, Vanderbrpeck M, Dombrowicz D and Hennen G (1989) Pituitary hormone dependent expression of insulinlike growth factor I and II in the immature hypophysectomized rat testis Molecular Endocrinology 3 1125-1131

D'Ercole AJ, Stiles AD and Underwood LE (1984) Tissue concentrations of somatomedin-C: further evidence for multiple sites of synthesis and paracrine or autocrine mechanisms of action Proceedings National Academy of Sciences USA 81 935-939

Forti G, Barni T, Vannelli BG, Balboni GC, Orlando C and Serio M (1989) Sertoli cell proteins in the human seminiferous tubule joumal of Steroid Biochemistry and Molecular Biology 32 135-144

Galdieri M, Monaco L and Stefanini M (1984) Secretion of androgen-binding protein by Sertoli cells is influenced by contact with germ cells Journal of Andrology 5 409-415

Gelber SJ, Hardy MP, Chamindrani Medis-Handagama SML and Casella SJ (1992) Effects of insulin-like growth factor-I on androgen production by highly purified pubertal and adult rat Leydig cells Joumal of Andrology 13 125-130

Grizzard JD, D'Ercole AJ, Wilkins JR, Moats-Staats BM and Williams RW (1984) Affinity-labeled somatomedin-C receptors and binding proteins from the human fetus Endocrinology 58 535-542

Handelsman DJ, Spaliviero JA, Scott CD and Baxter RC (1985) Identification of insulin-like growth factor-I and its receptors in the rat testis Acta Endocrinologica $109543-549$

Hansson HA, Nilsson A, Isgaard J, Billig H, Isaksson O, Skottner A, Andersson IK and Rozell B (1988) Immunohistochemical localization of insulin-like growth factor 1 in the adult rat Histochemistry 89 403-410

Hansson HA, Billig H and Isgaard J (1989) Insulin-like growth factor I in the developing and mature rat testis: immunohistochemical aspects Biology of Reproduction 40 1321-1328

Jacobs S, Cook S, Svoboda ME and Van Wyk JJ (1986) Interaction of the monoclonal antibodies $\alpha$ IR-I and $\alpha$ IR-3 with insulin and somatomedin-C receptors Endocrinology 118 223-226

Jaillard C, Chatelain PG and Saez JM (1987) In vitro regulation of pig Sertoli cell growth and function effects of fibroblast growth factor and somatomedin-C Biology of Reproduction 37 665-674

Kasson BG and Hsueh AJW (1987) Insulin-like growth factor-I augments gonadotropin-stimulated androgen biosynthesis by cultured rat testicular cells Molecular and Cellular Endocrinology 52 27-34

Kerr JB, Risbridger GP, Murray PJ and Knell CM (1988) Effect of unilateral cryptorchidism on the intertubular tissue of the adult rat testis: evidence for intracellular changes within the Leydig cells International Journal of Andrology 11 209-223

Kormano M (1967) Development of the rectum-testis temperature difference in the postnatal rat Journal of Reproduction and Ferility 14 427-4.37

Kull FC, Jr, Jacobs S, Su Y-F, Svoboda ME, Van Wyk JJ and Cuatrecasas P (1983) Monoclonal antibodies to receptors for insulin and somatomedin-C Journal of Biological Chemistry 258 6561-6566

Leheup BP and Grignon G (1993) Immunohistochemical localization of insulinlike growth factor I (IGF-1) in the rat epididymis Journal of Andrology 14 $159-163$

Leheup B, Gelly JL, Delongeas JL and Grignon G (1989) Paracrine factors and rat ductus epididymis maturation. In vivo and in vitro study of basement membranes and principal cell differentiation. In Developments in Ultrastructure of Reproduction. Progress in Clinical and Biological Research Vol. 296 pp 227-232 Ed. PM Motta. Alan R Liss, New York

Lin T, Haskell H and Vinson N (1986a) Characterization of insulin and insulinlike growth factor I receptors of purified Leydig cells and their role in steroidogenesis in primary culture: a comparative study Endocrinology 119 $1641-1647$
Lin T, Haskell J, Vinson N and Terracio L (1986b) Direct stimulatory effects of insulin-like growth factor I on Leydig cells steroidogenesis in primary culture Biochemical and Biophysical Research Communications 137 950-956

Lin T, Blaisdell J and Haskell JF (1987) Type I IGF receptors of Leydig cells are upregulated by human chorionic gonadotropin Biochemical and Biophysical Research Communications 149 852-858

Lin T, Blaisdell J and Haskell JF (1988) Hormonal regulation of type I insulin-like growth factor receptors of Leydig cell in hypophysectomised rats Endocrinology 123 134-139

Mita M, Borland K, Price JM and Hall PF (1985) The influence of insulin and insulin-like growth factor I on hexose transport by Sertoli cells Endocrinology $116987-992$

Nagpal ML, Wang D, Calkins JH, Chang W and Lin T (1991) Human chorionic gonadotropin up-regulates insulin-like growth factor-I receptor gene expression of Leydig cells Endocrinology 129 2820-2826

Naville D, Chatelain PG, Avallet O and Saez JM (1990) Control of production of insulin-like growth factor I by pig Leydig and Sertoli cells cultured alone or together: cell-cell interactions Molecular Cell Endocrinology 70 217-224

Oonk RB and Grootegoed JA (1988) Insulin-like growth factor I (IGF-I) receptors on Sertoli cells from immature rats and age-dependent testicular binding of IGF-I and insulin Molecular Cell Endocrinology 55 33-43

Oonk RB, Jansen R and Grootegoed JA (1989) Differential effects of folliclestimulating hormone, insulin and insulin-like growth factor I on hexose uptake and lactate production by rat Sertoli cells journal of Cellular Physiology 139 210-218

Perrard-Sapori MH, Chatelain P, Jaillard C and Saez JM (1987) Characterization and regulation of somatomedin-C/insulin-like growth factor I (Sm-C/IGF-I) receptors on cultured pig Leydig cells. Effects of Sm-C/IGF-I on luteotropin receptors and steroidogenesis European Journal of Biochemistry 103 209-214

Rajalakshmi M and Prasad MRN (1974) Changes in the epididymis of adult rats following experimentally induced cryptorchidism Andrologia 6 293-302

Risbridger GP, Kerr JB and de Kretser DM (1981) Evaluation of Leydig cell function and gonadotropin binding in unilateral cryptorchidism: evidence for local control of Leydig cell function by the seminiferous tubule Biology of Reproduction 24 534-540

Ritzen EM (1983) Chemical messengers between Sertoli cells and neighbouring cells Journal of Steroid Biochemistry and Molecular Biology 19 499-504

Skinner MK (1991) Cell-cell interactions in the testis Endocrine Reviews 12 $45-63$

Smith EP, Svododa ME, Van Wyk JJ, Kierszenbaum AL and Tres LL (1987) Partial characterization of a somatomedin-like peptide from the medium of cultured rat Sertoli cells Endocrinology 120 186-193

Smith EP, Dickson BA and Chernausek SD (1990) Insulin-like growth factor binding protein-3 secretion from cultured rat Sertoli cells: dual regulation by follicle stimulating hormone and insulin-like growth factor-J Endocrinology $1272744-2751$

Smith EP, Cheung PT, Ferguson A and Chernausek SD (1992) Mechanism of Sertoli cell insulin-like growth factor (IGF)-binding protein-3 regulation by IGF-I and adenosine $3^{\prime}, 5^{\prime}$-monophosphate Endocrinology 131 2733-2741

Söder O, Baurg P, Wahab A and Parvinen M (1992) Insulin-like growth factors selectively stimulate spermatogonial, but not meiotic, deoxyribonucleic acid synthesis during rat spermatogenesis Endocrinology 131 2344-2350

Spiteri-Grech J, Bartlett JMS and Nieschlag E (1991) Hormonal regulation of epidermal growth factor and insulin-like growth factor-I in adult male hypophysectomized rats treated with ethane dimethane sulphonate Journal of Endocrinology 129 109-117

Spiteri-Grech J, Weinbauer GF, Bolze P, Chandolia RK, Bartlett JMS and Nieschlag E (1993) Effects of FSH and testosterone on intratesticular insulin-like growth factor-I and specific germ cell populations in rats treated with gonadotrophin-releasing hormone antagonist Joumal of Endocrinology $13781-89$

Tres LL., Smith EP, Van Wyk JJ and Kierszenbaum AL (1986) Immunoreactive sites and accumulation of somatomedin-C in rat Sertoli-spermatogenic cell co-cultures Experimental Cell Research $162 \quad 33-50$

Vannelli BG, Barni T, Orlando C and Balboni GC (1988) Insulin-like growth factor-I (IGF-I) and IGF-I receptor in human testis: an immunohistochemical study Fertility and Sterility 49 666-669

Zhou J and Bondy C (1993a) Anatomy of the insulin-like growth factor system in the human testis Fertility and Sterility 60 897-904

Zhou J and Bondy C (1993b) Anatomy of the human ovarian insulin-like growth factor system Biology of Reproduction 48 467-482 